\title{
Engineering CAR-T cells
}

\author{
Cheng Zhang ${ }^{1}$, Jun Liu', Jiang F. Zhong ${ }^{2}$ and Xi Zhang ${ }^{1 *}$
}

\begin{abstract}
Chimeric antigen receptor redirected T cells (CAR-T cells) have achieved inspiring outcomes in patients with B cell malignancies, and are now being investigated in other hematologic malignancies and solid tumors. CAR-T cells are generated by the T cells from patients' or donors' blood. After the T cells are expanded and genetically modified, they are reinfused into the patients. However, many challenges still need to be resolved in order for this technology to gain widespread adoption. In this review, we first discuss the structure and evolution of chimeric antigen receptors. We then report on the tools used for production of CAR-T cells. Finally, we address the challenges posed by CAR-T cells.
\end{abstract}

Keywords: Chimeric antigen receptor redirected T cells, CAR-T cells, Structure, Evolution, Production, Viral vector

\section{Background}

Chimeric antigen receptors (CARs) are engineered receptors that can graft an arbitrary specificity onto an immune effector cell ( $\mathrm{T}$ cell). CARs include three parts: an extracellular antigen recognition domain of the single-chain Fragment variant $(\mathrm{scFv})$ derived from an antibody), a transmembrane domain and an intracellular $\mathrm{T}$ cell activation domain of $\mathrm{CD} 3 \zeta$ [1]. CAR-T cell therapy is designed to redirect a patient's or donor's $\mathrm{T}$ cells to specifically target and destroy tumor cells. This approach shows great promise for haematologic malignancies and solid tumors without major histocompatibility complex restriction [2]. In this review, we first discuss the structure and evolution of CARs. We then report on the tools used for production of CAR-T cells. Finally, we address the challenges posed by CAR-T cells.

\section{Structure of CAR-T cells}

CARs consist of an ectodomain, transmembrane domain and endodomain [3] (Fig. 1).

\section{Ectodomain}

The ectodomain is the domain of a membrane protein that is outside the cytoplasm and exposed to the extracellular space. The ectodomain in this case consists of signal peptide, antigen recognition region and spacer $[1,3]$.

\footnotetext{
* Correspondence: zhangxxi@sina.com

${ }^{1}$ Department of Hematology, Xinqiao Hospital, Third Military Medical

University, Chongqing 400037, People's Republic of China

Full list of author information is available at the end of the article
}

The role of a signal peptide is to direct the nascent protein into the endoplasmic reticulum. The $\mathrm{scFv}$, which serves as the signal peptide of the ectodomain in a CAR, is formed by the variable portions of heavy and light chains of an immunoglobulin fused through a flexible linker. An antigen recognition domain is usually a $\mathrm{scFv}$ with a simple ectodomain and more exotic recognition components, which can be used to recognize any antigen if it can bind targets with high affinity. The connection between the antigen binding domain and the transmembrane domain relied on the spacer. The simplest form of spacer is the hinge region of IgG1 and is sufficient for most scFv-based constructs.

\section{Transmembrane domain}

The transmembrane domain, from the most membraneproximal component of the endodomain, consists of a hydrophobic alpha helix that spans the membrane $[1,3,4]$. The stability of the receptor is related to the transmembrane domain. The presence of the native CD3zeta transmembrane can cause the incorporation of the artificial TCR into the native TCR. At present, the CD28 transmembrane domain is the most stable receptor.

\section{Endodomain}

The endodomain is the functional end of the receptor, and the most common component is $\mathrm{CD} 3 \zeta$ included three immunoreceptor tyrosine-based activation motifs (ITAMs) [3, 4]. After antigen recognition, the receptors 


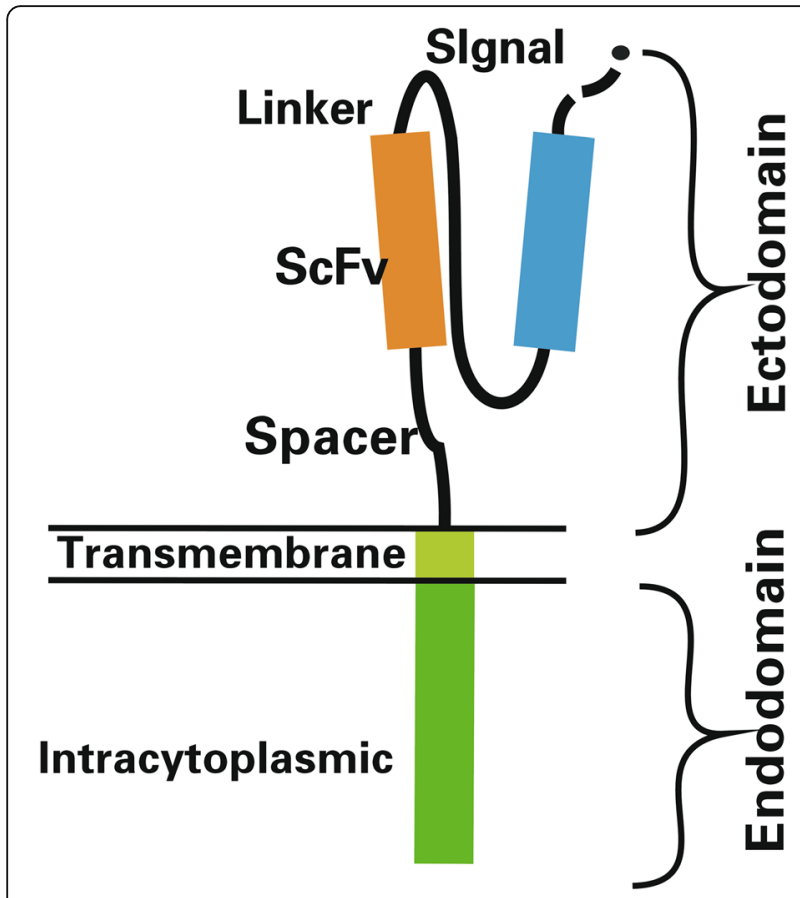

Fig. 1 Structure of chimeric antigen receptor (CAR). The CAR includes ectodomain, transmembrane domain and endodomain

cluster and signal was activated, then the sigal is transmitted to the T cell. Co-stimulatory signaling is needed during this profression.

\section{Evolution of CAR-T cells}

Since the initial development of CARs in 1989, CAR-T cells can be divided into four generations according to the structure of the endodomain (Fig. 2). The evolution of CAR therapy is an excellent example of the application of basic research to the clinic.

\section{First generation}

Single structure from the CD3 $\zeta$ - chain or FceRI $\gamma$ from the intracellular domain for the first generation of CARs is the typical characteristics, which is the primary transmitter of signals from endogenous T cell receptor (TCR) $[5,6]$. However, these CAR-T cells could not produce enough interleukin-2 (IL-2), so in order to kill tumor cells it was necessary to administer exogenous IL-2. Therefore, the first generation of CAR-T cell therapy transfected with single-chain receptors benefitted substantially from the accompanying administration of cytokines [7].

Recent studies showed that the deletion of phosphorylation on ITAM $\mathrm{A}$ and $\mathrm{C}$ in the $\mathrm{CD} 3 \zeta$ signaling moiety could decrease the apoptosis signal, which is beneficial for the continuous expression of the transgene [8, 9]. However, more studies were performed with CAR-T cells with the $\mathrm{CD} 3 \zeta$-chain than the FceRI $\gamma$-chain in clinics. The reason may be that three ITAMs were included in CD3 $\zeta$-chain, but only one in the FceRI $\gamma$-chain. On the other hand, the CAR-T cells with the CD3 -chain were more effective at activating $\mathrm{T}$ cells and killing tumor cells, although they had lower expression levels in vitro. The transmembrane domain of CAR-T cells consists of a dimer of homologous or heterologous in combinations of CD3, CD8 and CD28, which can mediate optimal cellular activation via the dimerization of CARs and the functional interaction of this receptor with the endogen-

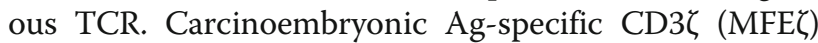
-CAR-T cells, alpha-folate receptor (FR) -CAR-T cells, CE7R-CAR-T cells, scFv(G250)-CAR-T cells, GD2-

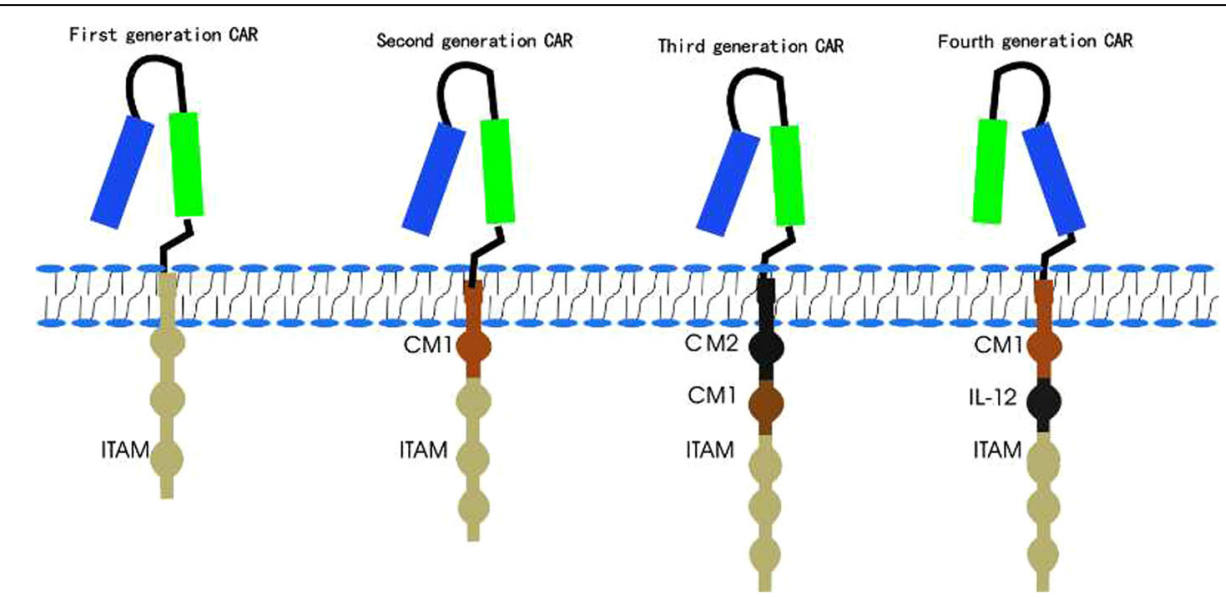

Fig. 2 Evolution of chimeric antigen receptor (CAR) from the first generation to the fourth generation. Single chain antibody (CD3द or FcERly) links the ITAM at transmembrane region for the first generation. Costimulatory molecule (CM1), such as CD28, has been engineered to the signal transduction region for the second generation. Another costimulatory molecule (CM2) based on the second generation for the third generation has been engineered to the signal transduction region, such as combining CD134 or CD137. The interleukin-12 (IL-12) based on the second generation for the fourth generation has been engineered to the signal transduction region. ITAM: Immunoreceptor tyrosine-based activation motifs 
CAR-Tcells and CD10- CAR-T cells were used to treat different tumors [10-15]. However, most of these studies with first-generation CAR-T cells did not achieve the desired outcomes because of inadequate proliferation, a short life span in vivo and insufficient secreted cytokines.

\section{Second generation}

Dual signal was the typical characteristics for $\mathrm{T}$ cell activation. Three different receptor types including the T-cell antigen receptors, cytokine receptors and costimulatory receptors are included in this progression. The first signal is the special signal that, triggered by the TCR, recognizes the antigenic peptide-MHC complex on the surface of antigen-presenting cells. The second signal is the co-stimulatory signal, produced by a costimulatory molecule such as CD28/B7, which promotes the IL-2 synthesis to complete the activation of $\mathrm{T}$ cells and avoid apoptosis. Naïve $\mathrm{T}$ cells cannot perform their normal role if the co-stimulatory signal is absent, and the same is true even if the $\mathrm{T}$ cells are stimulated by the

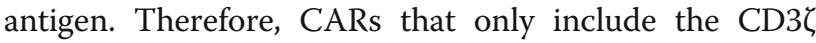
sequence cannot activate CAR-T cells without a costimulatory signal. Accordingly, second generation CARs added intracellular signaling domains from various costimulatory protein receptors to the cytoplasmic tail of the CARs to provide additional signals to the T cell, such as CD28 or CD137(4-1BB and CD134(OX40)), which can improve the proliferation, cytotoxicity, and sustained response, and prolong the life of CAR-T cells in vivo [16-18]. CD28-mediated co-stimulation is very important in the regulation of proliferation and survival for lymphocytes, and plays a key role for the establishment of memory cells and effector cells. CD134 can sustain proliferation and strengthen IL-2 production. CD137 can maintain the response signal of $\mathrm{T}$ cells, which plays a key role in the survival of $\mathrm{T}$ cells and the memory of $\mathrm{CD}^{+} \mathrm{T}$ cells [19-21]. The scFvCD19-CD137-CD3-CART cells, MOv19-BBC-CAR-T cells and scFvCD19-CD28$\mathrm{CD} 3 \zeta$-CAR-T cells were used to treat $\mathrm{B}$ cell malignancies, and achieved better outcomes than the first generation $[22,23]$. It seems that the 4-1BB - -CAR$\mathrm{T}$ cells have a longer persist time than $\mathrm{CD} 28 \mathrm{C}$-CAR- $\mathrm{T}$ cells, however, the direct comparisons is absent [24].

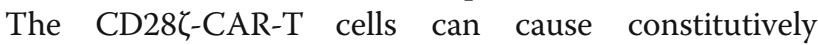
stimulation, proliferation and growth [25]. However, the 4-1BB - -CAR-T cells can induce early exhaustion, which may limit antitumor efficacy $[26,27]$.

\section{Third generation}

The third-generation CARs were made by combining multiple signaling domains, such as $\mathrm{CD} 3 \zeta-\mathrm{CD} 28-\mathrm{OX} 40$ or $\mathrm{CD} 3 \zeta-\mathrm{CD} 28-41 \mathrm{BB}$, to augment potency with stronger cytokine production and killing ability [28]. These scFv
CD20-CD28-CD137-CD3ל-CAR-T cells and HER2-CAR$\mathrm{T}$ cells were used to treat lymphoma and colon cancer; however, outcomes were not improved relative to the second generation $[29,30]$. The reason may be that the number of cases studied was small. Therefore, further studies are needed to explore the safety and efficacy of these treatments, and the selection of co-stimulatory molecules is also important.

\section{Fourth generation}

The fourth-generation CARs were generated by adding IL-12 to the base of the second-generation constructs, and are known as $\mathrm{T}$ cell redirected for universal cytokine-mediated killing (TRUCKs). TRUCKs augment T-cell activation and activate and attract innate immune cells to eliminate antigen-negative cancer cells in the targeted lesion. It would be worthwhile to explore the role of TRUCKs in shaping the tumor environment by the inducible release of transgenic immune modifiers. Such TRUCK $\mathrm{T}$ cells can also treat viral infections, metabolic disorders and auto-immune diseases [31].

Altogether, these successive generations of CAR-T cell therapy have generated a great deal of enthusiasm in cancer treatment [32].

\section{Tools of transduction for CAR-T cells}

A tool is needed for the delivery of the foreign gene into human cells. At present, there are two ways to accomplish gene incorporation with vectors, i.e., viral systems and non-viral systems.

The major vectors for gene therapy in basic research and clinical study are viruses, because of the high transfer efficiency, the relatively short time needed to reach the clinically necessary numbers of cultured $\mathrm{T}$ cells and the availability of different viruses with different expression characteristics. Most viral systems can accommodate genes from helpful and interesting cells and can provide the viral structural enzymes and proteins to allow for the generation of vector-containing infectious viral particles. The virus vectors include retroviruses (including lentivirus), adenovirus and adeno-associated virus. Among them, the most popular tools for gene delivery are genetically engineered retroviruses [33]. Retroviridae is a family of retroviruses. In this family, amino acid and nucleotide sequence, genome structure, pathogenicity and host range is difference. However, the virus vectors pose a potential safety hazard. The insertion mutation used to induce the immune reaction can lead to tumorigenesis and toxicity, the carrier capacity is limited and the titer achieved is not high enough [33, 34].

Non-viral gene therapy has maintained its position as an approach for treating cancer because of its higher efficiency, target specificity, non-infectiousness, unlimited 
carrier capacity, controlled chemical constitution and generous production, $[35,36]$. Non-viral vectors include nude DNA, liposomes, polymerizers and molecular conjugates. Minicircle DNA vectors free of plasmid bacterial DNA sequences are novel non-viral vectors which are generated in bacteria from a parental plasmid, and can persistently express transgene with high levels in vivo. It is practicable in clinics for this method $[37,38]$.

\section{Production of CAR-T Cells}

Several steps are required for the production of CAR-T cells. It is also very important to conduct quality control testing throughout the entire protocol [39].

First, leukocytes are taken from the patient's or donor's body using leukapheresis. Second, The T cells are enriched and washed to separate them from the leukocytes [40]. Third, the $\mathrm{T}$ cell subsets at the level of CD4/CD8 composition are separated using specific antibody bead conjugates or markers. Culture is then needed to activate the $\mathrm{T}$ cells. This process requires purifying autologous antigen-presenting cells (APCs) from the patients or donors, or beads coated with anti-CD3/anti-CD28 monoclonal antibodies, or antiCD3 antibodies alone or in combination with feeder cells and growth factors, such as IL-2. IL-2 is the most commonly used agent because it induces rapid $\mathrm{T}$ cell growth. In order to polarize $\mathrm{T}$ cells to a specific phenotype, the culture conditions are further refined [41].

CARs are encoded with viral vectors, which guide the RNA to reverse-transcribe into DNA and permanently integrate into the genome of the patient cells. The viral vector is washed out of the culture via medium exchange and/or dilution during the activation process. Lentiviral vectors are more commonly used than gammaretroviral vectors in clinical trials because of their safer integration site profile [42]. The other methods includes Sleeping Beauty transposon system and mRNA transfection. However, many concerns remain, such as the requirement for several rounds of infusion using transient mRNA transfection and the unknown potential of insertional mutagenesis and remobilization of transposons when using the Sleeping Beauty transposon system [43].

Three bioreactor culture systems are used to culture CAR-T cells: WAVE Bioreactor, G-Rex and CliniMACS Prodigy [44]. The major drawback of the former two systems is that the flask must be opened during cell inoculation. However, the CliniMACS Prodicy system is a single device that can effectively enrich, activate, transducer and expand the cells [45]. After the cells reach the numbers required for clinical uses, they are collected and transfused into the patients.

\section{Challenges for CAR-T cell therapy}

Although CAR-T cells have been used in clinics, many questions still need to be addressed, such as the optimal vector and the long-term safety profile.

The key raw material for the CAR-T cell product is the viral vector that transduces the CARs into the $\mathrm{T}$ cells. The viral vector encoding the CARs can be made in large quantities and stored at $-80{ }^{\circ} \mathrm{C}$ even for about 9 years [46]. Therefore, the sterility of the vector is crucial because these cells will be infused into the patients. The third-generation minimal lentiviral vector may be the safest one that has been developed thus far [47]. Quality control testing on the safety, sterility, titer, purity and potency is absolutely crucial. The comparison of vector purity, stability, and function is also important because vectors can be obtained from different suppliers. It would be most desirable to control these variables by using a single vector for the generation of CAR-T cells.

The potential for insertional mutagenesis caused by the integration of vector DNA into host cells is a concern. Lentiviral vectors may have a lower risk of mutagenesis than others [48]. However, both lentiviral and retroviral vectors are potentially oncogenic. The longterm safety of using viral vectors for CAR-T cell therapy remains unknown. Therefore, it is necessary to monitor carefully for any potential delayed adverse event related to these vectors for an extended period of time. The effects of persistent CAR-T cells on future pregnancies are also unknown.

Effective coordination among the collection, manufacturing, and treatment sites is crucial in order to ensure correct handling of the material and appropriate scheduling of patients during the therapeutic process. It is therefore very important to develop a standardized manufacturing process for CAR-T cells in order to establish the critical quality characteristics and target product profile. It is also important to gain more experience with these procedures because the CARs positivity, phenotype and viability vary among different products [49]. Comparing products is difficult because of the variability between the starting materials generated from leukapheresis.

The good results were observed in clinics with CAR-T cells therapy in hematological malignancies, however, it is still a change in the solid tumors because of antigen loss in tumor cells, the lack of unique antigens and the immune-suppressive tumor microenvironment of solid tumors $[50,51]$. So in order to improve the effect of CAR-T cells therapy, many progresses have been made by incorporating CARs with another effector molecules such as PD1 switch receptors, anti-oxidant enzymes, matrix degradation enzymes and so on [52-56].

The major adverse effect observed after CAR-T cell therapy is severe cytokine release syndrome (CRS). Although most of the adverse events subsequent to 
CAR-T cell therapy can be managed with currently available interventions, it is nevertheless important to reduce the adverse effects while maintaining the efficacy of the treatment [57]. Similarly, it is also important to increase the safety of CAR-T cell therapy when improving the specificity of the modified $\mathrm{T}$ cells.

\section{Conclusion}

CAR-T treatment for patients with tumors has shown promising outcomes; however, many remaining challenges need to be considered [58]. The high quality of CAR-T products needs to be ensured through optimization of protocols, and the long-term safety requires further study [59].

\section{Abbreviations}

CARs: Chimeric antigen receptors; CAR-T cells: Chimeric antigen receptor redirected T cells; scFv: Single-chain Fragment variant;

ITAMs: immunoreceptor tyrosine-based activation motifs; IL-2: Interleukin-2; TCR: T cell receptor; TRUCKs: T cell redirected for universal cytokine-mediated killing; APCs: Antigen-presenting cells; CRS: Cytokine release syndrome

\section{Acknowledgements}

Not applicable.

\section{Funding}

This study was funded by the clinical key foundation of Xinqiao Hospital of Third Military Medical University (No. 2016YLC03)

\section{Availability of data and materials}

Data sharing not applicable to this article as no datasets were generated or analysed during the current study.

\section{Authors' contributions}

$\sqcup J$ and ZC wrote the paper. ZX and ZJF revised the paper. All authors collected the data, read and approved the final manuscript.

\section{Competing interests}

The authors declare that they have no competing interests.

\section{Consent for publication}

Not applicable.

\section{Ethics approval and consent to participate}

Not applicable.

\section{Author details \\ 'Department of Hematology, Xinqiao Hospital, Third Military Medical University, Chongqing 400037, People's Republic of China. ${ }^{2}$ Division of Periodontology, Diagnostic Sciences \& Dental Hygiene, and Division of Biomedical Sciences, Herman Ostrow School of Dentistry, University of Southern California, Los Angeles, CA, USA.}

Received: 27 April 2017 Accepted: 2 June 2017

Published online: 24 June 2017

\section{References}

1. Ramos CA, Dotti G. Chimeric antigen receptor (CAR)-engineered lymphocytes for cancer therapy. Expert Opin Biol Ther. 2011;11(7):855-73.

2. Lipowska-Bhalla G, Gilham DE, Hawkins RE, Rothwell DG. Targeted immunotherapy of cancer with CAR T cells: achievements and challenges. Cancer Immunol Immunother. 2012;61(7):953-62.

3. Liu J, Zhong JF, Zhang X, Zhang C. Allogeneic CD19-CAR-T cell infusion after allogeneic hematopoietic stem cell transplantation in B cell malignancies. J Hematol Oncol. 2017;10(1):35.
4. Tasian SK, Gardner RA. CD19-redirected chimeric antigen receptor-modified T cells: a promising immunotherapy for children and adults with B-cell acute lymphoblastic leukemia (ALL). Ther Adv Hematol. 2015;6(5):228-41.

5. Gross G, Waks T, Eshhar Z. Expression of immunoglobulin-T-cell receptor chimeric molecules as functional receptors with antibody-type specificity. Proc Natl Acad Sci U S A. 1989;86(24):10024-8.

6. Eshhar Z, Waks T, Gross G, Schindler DG. Specific activation and targeting of cytotoxic lymphocytes through chimeric single chains consisting of antibodybinding domains and the gamma or zeta subunits of the immunoglobulin and T-cell receptors. Proc Natl Acad Sci U S A. 1993;90(2):720-4.

7. Brocker T. Chimeric Fv-zeta or Fv-epsilon receptors are not sufficient to induce activation or cytokine production in peripheral T cells. Blood. 2000; 96(5):1999-2001.

8. Heuser C, Hombach A, Lösch C, Manista K, Abken H. T-cell activation by recombinant immunore-ceptors: impact of the intracellular signalling domain on the stability of receptor expression and antigen-speciic activation of grafted T cells. Gene Ther. 2003;10(17):1408-19.

9. Zhao Y, Wang QJ, Yang S, Kochenderfer JN, Zheng Z, Zhong X, et al. A herceptin-based chimeric antigen receptor with modified signaling domains leads to enhanced survival of transduced T lymphocytes and antitumor activity. J Immunol. 2009;183(9):5563-74.

10. Bridgeman JS, Hawkins RE, Bagley S, Blaylock M, Holland M, Gilham DE. The optimal antigen response of chimeric antigen receptors harboring the CD3zeta transmembrane domain is dependent upon incorporation of the receptor into the endogenous TCR/CD3 complex. J Immunol. 2010;184(12): 6938-49.

11. Kershaw MH, Westwood JA, Parker LL, Wang G, Eshhar Z, Mavroukakis SA, et al. A phase I study on adoptive immunotherapy using gene-modified T cells for ovarian cancer. Clin Cancer Res. 2006;12(20 Pt 1):6106-15.

12. Julie RP, David LD, Marilyn S, Wright C, Naranjo A, Wagner J, et al. Adoptive transfer of chimeric antigen receptor re-directed cytolytic T lymphocyte clones in patients with Neuroblastoma. Mol Ther. 2007;15(4):825-33.

13. Lamers CH, Langeveld SC, Groot-van Ruijven CM, Debets R, Sleijfer S, Gratama JW, et al. Gene-modified T cells for adoptive immunotherapy of renal cell cancer maintain transgene-specific immune functions in vivo. Cancer Immunol Immunother. 2007;56(12):1875-83.

14. Pule MA, Savoldo B, Myers GD, Rossig C, Russell HV, Dotti G, et al. Virusspecfic $T$ cells engineered to coexpress tumor-speciic receptors: Persistence and antitumor activity in individuals with neuroblastoma. Nat Med. 2008; 14(11):1264-70

15. Till BG, Jensen MC, Wang J, Chen EY, Wood BL, Greisman HA, et al. Adoptive immunotherapy for indolent non-Hodgkin lymphoma and mantle cell lymphoma using genetically modified autologous CD20-specific T cells. Blood. 2008;112(6):2261-71.

16. Finney HM, Lawson AD, Bebbington CR, Weir AN. Chimeric receptors providing both primary and costimulatory signaling in T cells from a single gene product. J Immunol. 1998;161(6):2791-7.

17. Dotti G, Savoldo B, Brenner M. Fifteen years of gene therapy based on chimeric antigen receptors: Are we nearly there yet? Hum Gene Ther. 2009; 20(11):1229-39.

18. Park TS, Rosenberg SA, Morgan RA. Treating cancer with genetically engineered T cells. Trends Biotechnol. 2011;29(11):550-7.

19. Acuto O, Michel F. CD28-mediated co-stimulation: a quantitative support for TCR signalling. Nat Rev Immunol. 2003;3(12):939-51.

20. Finney HM, Akbar AN, Lawson AD. Activation of resting human primary $T$ cells with chimeric receptors: Costimulation from CD28, inducible costimulator, CD134, and CD137 in series with signals from the TCR zeta chain. J Immunol. 2004;172(1):104-13.

21. Croft M. The role of TNF superfamily members in T-cell function and diseases. Nat Rev Immunol. 2009;9(4):271-85.

22. Cai B, Guo M, Wang Y, Zhang Y, Yang J, Guo Y, et al. Co-infusion of haploidentical CD19-chimeric antigen receptor $T$ cells and stem cells achieved full donor engraftment in refractory acute lymphoblastic leukemia. J Hematol Oncol. 2016;9(1):131.

23. Hu Y, Sun J, Wu Z, Yu J, Cui Q, Pu C, et al. Predominant cerebral cytokine release syndrome in CD19-directed chimeric antigen receptor-modified T cell therapy. J Hematol Oncol. 2016;9(1):70.

24. Porter DL, Hwang WT, Frey NV, Lacey SF, Shaw PA, Loren AW, et al. Chimeric antigen receptor $\mathrm{T}$ cells persist and induce sustained remissions in relapsed refractory chronic lymphocytic leukemia. Sci Transl Med. 2015; 7(303):303ra139 
25. Frigault MJ, Lee J, Basil MC, Carpenito C, Motohashi S, Scholler J, et al. Identification of chimeric antigen receptors that mediate constitutive or inducible proliferation of T cells. Cancer Immunol Res. 2015;3(4):356-67.

26. Long $\mathrm{AH}$, Haso WM, Shern JF, Wanhainen KM, Murgai $M$, Ingaramo $M$, et al. 4-1BB costimulation ameliorates $T$ cell exhaustion induced by tonic signaling of chimeric antigen receptors. Nat Med. 2015;21(6):581-90.

27. Kawalekar OU, O'Connor RS, Fraietta JA, Guo L, McGettigan SE, Posey AD Jr, et al. Distinct signaling of coreceptors regulates specific metabolism pathways and impacts memory development in CAR T cells. Immunity. 2016:44(2):380-90.

28. Marin V, Pizzitola I, Agostoni V, Attianese GM, Finney H, Lawson A, et al. Cytokine-induced killer cells for cell therapy of acute myeloid leukemia: improvement of their immune activity by expression of CD33-specific chimeric receptors. Haematologica. 2010;95(12):2144-52.

29. Till BG, Jensen MC, Wang J, Qian X, Gopal AK, Maloney DG, et al. CD20specific adoptive immunotherapy for lymphoma using a chimeric antigen receptor with both CD28 and 4-1BB domains: pilot clinical trial results. Blood. 2012;119(17):3940-50.

30. Morgan RA, Yang JC, Kitano M, Dudley ME, Laurencot CM, Rosenberg SA. Case report of a serious adverse event following the administration of T cells transduced with a chimeric antigen receptor recognizing ERBB2. Mol Ther. 2010;18(4):843-51.

31. Chmielewski M, Abken H. TRUCKs: the fourth generation of CARs. Expert Opin Biol Ther. 2015;15(8):1145-54.

32. Sha HH, Wang DD, Yan DL, Hu Y, Yang SJ, Liu SW, et al. Chimaeric antigen receptor T-cell therapy for tumour immunotherapy. Biosci Rep. 2017;37(1).

33. Hu WS, Pathak VK. Design of retroviral vectors and helper cells for gene therapy. Pharmacol Rev. 2000;52(4):493-511.

34. Wang GP, Garrigue A, Ciuffi A, Ronen K, Leipzig J, Berry C, et al. DNA bar coding and pyrosequencing to analyze adverse events in therapeutic gene transfer. Nucleic Acids Res. 2008;36(9):e49.

35. El-Aneed A. An overview of current delivery systems in cancer gene therapy. J Control Release. 2004;94(1):1-14.

36. Pahle J, Walther $W$. Vectors and strategies for nonviral cancer gene therapy. Expert Opin Biol Ther. 2016;16(4):443-61

37. Chen ZY, He CY, Kay MA. Improved production and purification of minicircle DNA vector free of plasmid bacterial sequences and capable of persistent transgene expression in vivo. Hum Gene Ther. 2005;16(1):126-31.

38. Kay MA, He CY, Chen ZY. A robust system for production of minicircle DNA vectors. Nat Biotechnol. 2010:28(12):1287-9.

39. Levine BL. Performance-enhancing drugs: design and production of redirected chimeric antigen receptor (CAR) T cells. Cancer Gene Ther. 2015; 22(2):79-84

40. Lee G, Arepally GM, et al. J Clin Apher. 2012;27:117-25.

41. Guedan S, Chen X, Madar A, Carpenito C, McGettigan SE, Frigault MJ, et al. (2014). ICOS-based chimeric antigen receptors program bipolar TH17/TH1 cells. Blood. 2014;124(7):1070-80.

42. McGarrity GJ, Hoyah G, Winemiller A, Andre K, Stein D, Blick G, et al. Patient monitoring and follow-up in lentiviral clinical trials. J Gene Med. 2013;15(2):78-82.

43. Beatty GL, Haas AR, Maus MV, Torigian DA, Soulen MC, Plesa G, et al. Mesothelin-specific chimeric antigen receptor mRNA-engineered T cells induce anti-tumor activity in solid malignancies. Cancer Immunol Res. 2014; 2(2):112-20.

44. Bajgain P, Mucharla R, Wilson J, Welch D, Anurathapan U, Liang B, et al. Optimizing the production of suspension cells using the G-Rex " $\mathrm{M}$ " series. Mol Ther Methods Clin Dev. 2014;1:14015.

45. Mock U, Nickolay L, Cheung G, Zhan H, Peggs K, Johnston I, et al. Automated lentiviral transduction of T cells with CARs using the CliniMACS Prodigy. Blood. 2015;11(2):A26-6.

46. Przybylowski M, Hakakha A, Stefanski J, Hodges J, Sadelain M, Rivière I. Production scale-up and validation of packaging cell clearance of clinical grade retroviral vector stocks produced in cell factories. Gene Ther. 2006; 13(1):95-100

47. Dull T, Zufferey R, Kelly M, Mandel RJ, Nguyen M, Trono D, et al. A thirdgeneration lentivirus vector with a conditional packaging system. J Virol. 1998;72(11):8463-71.

48. Vannucci L, Lai M, Chiuppesi F, Ceccherini-Nelli L, Pistello M. Viral vectors: a look back and ahead on gene transfer technology. New Microbiol. 2013; 36(1):1-22.
49. Porter $\mathrm{DL}$, Levine $\mathrm{BL}$, Kalos $\mathrm{M}$, Bagg A, June $\mathrm{CH}$. Chimeric antigen receptormodified T cells in chronic lymphoid leukemia. N Engl J Med. 2011;365(8): 725-33.

50. Yu S, Li A, Liu Q, Li T, Yuan X, Han X, et al. Chimeric antigen receptor T cells: a novel therapy for solid tumors. J Hematol Oncol. 2017;10(1):78.

51. Kato D, Yaguchi T, Iwata T, Morii K, Nakagawa T, Nishimura R, et al. Prospects for personalized combination immunotherapy for solid tumors based on adoptive cell therapies and immune checkpoint blockade therapies. Nihon Rinsho Meneki Gakkai Kaishi. 2017;40(1):68-77.

52. Morsut L, Roybal KT, Xiong X, Gordley RM, Coyle SM, Thomson M, et al. Engineering customized cell sensing and response behaviors using synthetic notch receptors. Cell. 2016;164(4):780-91.

53. Roybal KT, Rupp LJ, Morsut L, Walker WJ, McNally KA, Park JS, et al. Precision tumor recognition by $T$ cells with combinatorial antigen-sensing circuits Cell. 2016:164(4):770-9.

54. Newick K, O'Brien S, Sun J, Kapoor V, Maceyko S, Lo A, et al. Augmentation of CAR T-cell trafficking and antitumor efficacy by blocking protein kinase A localization. Cancer Immunol Res. 2016;4(6):541-51.

55. Caruana I, Savoldo B, Hoyos V, Weber G, Liu H, Kim ES, et al. Heparanase promotes tumor infiltration and antitumor activity of CAR-redirected $T$ lymphocytes. Nat Med. 2015;21(5):524-9.

56. Rodgers DT, Mazagova M, Hampton EN, Cao Y, Ramadoss NS, Hardy IR, et al. Switch-mediated activation and retargeting of CAR-T cells for B-cell malignancies. Proc Natl Acad Sci U S A. 2016;113(4):E459-68.

57. Lee DW, Gardner R, Porter DL, Louis CU, Ahmed N, Jensen M, et al. Current concepts in the diagnosis and management of cytokine release syndrome. Blood. 2014;124(2):188-95.

58. Levine BL, Miskin J, Wonnacott K, Keir C. Global Manufacturing of CAR T Cell Therapy. Mol Ther Methods Clin Dev. 2016;4:92-101.

59. Wang Z, Wu Z, Liu Y, Han W. New development in CAR-T cell therapy. J Hematol Oncol. 2017:10(1):53.

\section{Submit your next manuscript to BioMed Central and we will help you at every step:}

- We accept pre-submission inquiries

- Our selector tool helps you to find the most relevant journal

- We provide round the clock customer support

- Convenient online submission

- Thorough peer review

- Inclusion in PubMed and all major indexing services

- Maximum visibility for your research

Submit your manuscript at www.biomedcentral.com/submit
) Biomed Central 